\title{
Cysteine cathepsins as regulators of the cytotoxicity of NK and T cells
}

\author{
Milica Perišić Nanut ${ }^{1}$, Jerica Sabotič ${ }^{1}$, Anahid Jewett ${ }^{2}$ and Janko Kos ${ }^{1,3} *$ \\ ' Department of Biotechnology, Jožef Stefan Institute, Ljubljana, Slovenia \\ 2 Division of Oral Biology and Medicine, The Jane and Jerry Weintraub Center for Reconstructive Biotechnology, UCLA School of Dentistry, University of California \\ Los Angeles, Los Angeles, CA, USA \\ ${ }^{3}$ Faculty of Pharmacy, University of Ljubljana, Ljubljana, Slovenia
}

\section{Edited by:}

Fabrizio Mattei, Istituto Superiore di Sanità, Italy

Reviewed by:

Masaaki Murakami, Hokkaido

University, Japan

Olga Vasiljeva, CytomXTherapeutics Inc., USA

${ }^{*}$ Correspondence:

Janko Kos, Faculty of Pharmacy,

University of Ljubljana, Askerceva 7,

1000 Ljubljana, Slovenia

e-mail: janko.kos@ffa.uni-lj.si
Cysteine cathepsins are lysosomal peptidases involved at different levels in the processes of the innate and adaptive immune responses. Some, such as cathepsins $B, L$, and $H$ are expressed constitutively in most immune cells. In cells of innate immunity they play a role in cell adhesion and phagocytosis. Other cysteine cathepsins are expressed more specifically. Cathepsin $\mathrm{X}$ promotes dendritic cell maturation, adhesion of macrophages, and migration of $\mathrm{T}$ cells. Cathepsin $\mathrm{S}$ is implicated in major histocompatibility complex class II antigen presentation, whereas cathepsin C, expressed in cytotoxic T lymphocytes and natural killer (NK) cells, is involved in processing pro-granzymes into proteolytically active forms, which trigger cell death in their target cells. The activity of cysteine cathepsins is controlled by endogenous cystatins, cysteine protease inhibitors. Of these, cystatin Fis the only cystatin that is localized in endosomal/lysosomal vesicles. After proteolytic removal of its $\mathrm{N}$-terminal peptide, cystatin $\mathrm{F}$ becomes a potent inhibitor of cathepsin $\mathrm{C}$ with the potential to regulate pro-granzyme processing and cell cytotoxicity. This review is focused on the role of cysteine cathepsins and their inhibitors in the molecular mechanisms leading to the cytotoxic activity of T lymphocytes and NK cells in order to address new possibilities for regulation of their function in pathological processes.

Keywords: cathepsins, cystatins, cytotoxicity, natural killer cells, cytotoxic $\mathrm{T}$ cells

\section{INTRODUCTION}

Peptidases are enzymes that catalyze the hydrolysis of peptide bonds in a polypeptide chain. On the basis of their catalytic mechanism they can be divided into seven main groups: cysteine, serine, aspartyl, asparagine, glutamic, threonine, and metallo peptidases (1). Exopeptidases remove residues from $\mathrm{N}$ - or $\mathrm{C}$-terminal end of the polypeptide chain, whereas endopeptidases catalyze the cleavage or hydrolysis of peptide bonds within the polypeptide chain. Furthermore, peptidases can act degradatively, causing complete breakdown of the targeted protein substrate, or regulatorily, cleaving one or more specific bonds, thus, altering the biological function of the target. In biological systems, the proteolytic activity of peptidases is controlled by a variety of mechanisms: (1) regulation of their expression at transcriptional and/or translational levels; (2) synthesis of peptidases as inactive zymogens; (3) activation of peptidases by co-factors; (4) recognition and cleavage of a particular peptide bond flanked by specific amino acids; (5) compartmentalization in granules or endolysosomal vesicles thus separating them from their substrates; and (6) binding of peptidase inhibitors to the active site preventing access to substrates (2). In this review, only the latter, i.e., the control of their activity by protease inhibitors is described in more detail.

Peptidases are involved in many biological processes, the most studied being protein catabolism and apoptosis as well as their role in inflammation, regulation of hormone processing, bone resorption, and blood clotting. In immune processes, the peptidases control key functions of innate and adaptive immune responses such as antigen processing and presentation to $\mathrm{T}$ cells, host-pathogen cross-talk, cell cytotoxicity, and resistance to bacterial and viral infections (3). Their dysregulated function has been associated with various pathological processes including processes related to altered function of the immune response, such as inflammation, allergies, autoimmune disorders, and impaired anti-tumor immune response (4-6). The role of cysteine cathepsins in regulating the cytotoxicity of cytotoxic $\mathrm{T}$ lymphocytes (CTLs) and natural killer (NK) cells is particularly addressed in this review in order to highlight the recent developments in this field and to emphasize the importance of these peptidases and their endogenous and exogenous inhibitors for normal functioning of important effector cells of the cellular immune response.

Of the numerous peptidases involved in physiological and pathological processes of the immune response, a group of endolysosomal cysteine peptidases, also named cysteine cathepsins, attracted a lot of attention during last years. The best known roles of cysteine cathepsins in these processes are their contributions to major histocompatibility complex (MHC) class II antigen presentation, cytokine and growth factor degradation, promotion of adhesion and migration of immune cells and regulation of cell cytotoxicity by processing pro-granzymes into proteolytically active forms $(5,7-9)$. The role of cysteine cathepsins in regulating the cytotoxicity of CTLs and NK cells is particularly addressed in this review in order to highlight the recent developments in this 
field and to emphasize the importance of these peptidases and their endogenous and exogenous inhibitors for normal functioning of important effector cells of the cellular immune response.

\section{CYSTEINE CATHEPSINS}

In the human genome, there are 561 genes encoding peptidases. Of these, 148 encode cysteine peptidases, among them a group of 11 lysosomal cysteine peptidases, the cathepsins (10). Cysteine cathepsins exhibit different level of expression and specificities, all of which contribute to their different physiological functions. Some of cathepsins, like B, H, L, and C, are ubiquitous in cells and tissues, whereas others, such as cathepsins S, X, V, O, F, K, and W can be found only in specific cell types.

The majority of cysteine cathepsins act as endopeptidases, the exopeptidases are cathepsins $\mathrm{B}, \mathrm{C}, \mathrm{X}$, and $\mathrm{H}(1,11)$. The exopeptidases possess additional structural elements in the vicinity of their active sites that prevent binding of extended natural substrates into the active site cleft and providing additional segments to facilitate binding of the $\mathrm{C}$ - or N-terminal end of the substrate $(12,13)$. Owing to these structural differences cathepsins B (also known as cathepsin B1 and longipain) and $\mathrm{X}$ (also known as cathepsin, Z, P, IV/B2/Y and lysosomal carboxypeptidase B) can act by cleaving their substrates as a dipeptidylcarboxypeptidase and a carboxymonopeptidase, respectively $(14,15)$ while cathepsins C (also known as cathepsin J and dipeptidyl peptidase I - DPPI) and $\mathrm{H}$ (also known as cathepsin B3/I) cleave their substrates as aminopeptidases $(1,16)$. Cathepsins $B$ and $H$ may retain their endopeptidase activity, in addition to their exopeptidase activity, depending on the local $\mathrm{pH}(17,18)$. Cysteine cathepsins were classified as cathepsin L-like and cathepsin B-like enzymes on the basis of the ERFNIN motif that is conserved in the propeptide of cathepsin L-like enzymes, but not cathepsin B-like enzymes (19). However, considering the structural and genetic data available in recent years, they can be divided into at least four groups (B-, L-, $\mathrm{X}-$, and C-like cathepsins) (20).

Cysteine cathepsins were long viewed as enzymes involved in final protein degradation in the lysosomes. More recently, they have been associated with more specific functions in a variety of important physiological and pathological processes (21). Cysteine cathepsins can be implicated also in processes occurring outside lysosomes, e.g., in the nucleus, on the cell membrane, the cytosol, and they can even be secreted into the extracellular environment (3).

\section{ENDOGENOUS AND EXOGENOUS INHIBITORS OF CYSTEINE CATHEPSINS}

The activity of cysteine cathepsins is ultimately controlled by endogenous peptidase inhibitors, such as cystatins, thyropins, propeptides, members of the serpin (serine peptidase inhibitors) family, and by the general peptidase inhibitor $\alpha 2$-macroglobulin (22). Among them the most important are cystatins that comprise a superfamily of evolutionarily related proteins present in all living organisms, and also in viruses. Type I cystatins (also known as stefins) are cytosolic and nuclear proteins. They are 100 amino acid long, single chain proteins, they do not contain disulfide bonds and are not glycosylated (23). In contrast, type II cystatins are typical extracellular proteins, 120 amino acid long, possessing two disulfide bonds (24). The members of family II are cystatins $\mathrm{C}, \mathrm{E} / \mathrm{M}, \mathrm{F}, \mathrm{D}, \mathrm{S}, \mathrm{SA}$, and $\mathrm{SN}$, and male reproductive tract cystatins $8,9,11,12$, CRES2, CRES3, cystatin 13, and cystatin 14 (1). Kininogens, large, multifunctional plasma proteins, represent type III cystatins. They contain three type II cystatin-like domains and they are precursors of the vasoactive peptide kinin (25). Fetuins and latexins represent additional protein families and comprise two cystatin-like domains; however, they do not exhibit inhibitory activity against cysteine peptidases (23). The tertiary structure of cystatins is conserved and exhibits the typical cystatin fold (26). The N-terminal segment and two cystatin loops form a wedgeshaped edge that is complementary to the active site cleft of the peptidase. Cystatins are tight-binding inhibitors of the $\mathrm{C} 1$ family of cysteine peptidases, while some type II cystatins ( $\mathrm{C}, \mathrm{E} / \mathrm{M}$, and $\mathrm{F}$ ) also have a second reactive site for inhibiting members of the $\mathrm{C} 13$ family of cysteine peptidases (27). Physiologically, cystatins regulate excessive cysteine proteinase activity in cells, tissues, and body fluids. In general, they act as "emergency" inhibitors, trapping and neutralizing peptidase activity. However, cystatins are present in cytoplasm and in extracellular fluids whereas their targets, cysteine cathepsins, are localized predominantly in lysosomes. Therefore, it is not clear under what circumstances cystatins meet their targets. In recent studies, it was shown that secreted type II cystatins can be internalized by immune or tumor cells, accumulating in endosomal/lysosomal vesicles $(28,29)$. The vesicular localization of cystatins may result in affecting a number of cell functions.

The number of exogenous inhibitors capable of inhibiting cysteine cathepsins is increasing and comprises protein and nonprotein molecules isolated from animals, microorganisms, plants, and fungi, neutralizing monoclonal antibodies and small synthetic molecules. However, only a few of them have the potential to be applied in clinical studies for treating diseases associated with an excessive activity of cysteine cathepsins. Among the inhibitors of animal, plant, and microbial origin the best known cysteine peptidase inhibitor is E-64 (1-[L-N-(trans-epoxysuccinyl)leucyl] amino-4-guanidinobutane), isolated from Aspergillus japonicus (30). Its epoxysuccinyl scaffold has served for the synthesis of a series of derivatives with improved specificity toward particular peptidases (31). Owing to their poor cell permeability, off-target binding, and the irreversible nature of their inhibition, the epoxysuccinyl inhibitors have not been introduced into clinical practice. The development of synthetic peptidase inhibitors has been directed toward reversible inhibitors that bind peptidases either covalently or non-covalently (32). Some of them have proved promising at the preclinical level and are therefore good candidates to enter clinical testing in the near future.

\section{CYTOTOXIC CELLS}

Cytotoxic T lymphocytes and NK cells are the major components in the effector arm of the cellular immune response against pathogen infected and tumor cells. Despite many fundamental biological differences between them, both CTLs and NK cells employ the same mechanism to initiate target cell apoptosis. One involves the death receptor pathway, encompassing Fas (CD95)Fas ligand (CD95L) and related death receptor mediated pathways (33). The other is the granule exocytosis pathway, and involves regulated release of the contents of cytotoxic granules into the 
immunological synapse formed between the effector and target cell (33). The granule exocytosis pathway is the principal killing mechanism employed by CTLs and NK cells in combating numerous viral infections (33-35) as well as some tumors $(36,37)$. It is also an important pathogenic mechanism underlying organ allograft rejection and graft vs. host disease $(35,38)$.

The key components that induce cell death in target cells are contained in cytotoxic granules, complex organelles that combine specialized storage and secretory functions with general degradative functions of typical lysosomes $(39,40)$. The most prominent components of this "death cargo" are perforin and a family of serine proteases, termed granzymes (39). In addition, cytotoxic granules contain several important lysosomal hydrolases including peptidases cysteine cathepsins $\mathrm{C}, \mathrm{H}$, and $\mathrm{L}$, as well as lysosomal membrane proteins Lamp-1, Lamp-2, and Lamp-3 (41, 42).

Perforin is a calcium-dependent, pore-forming member of the membrane attack complex/PRF (MACPF) protein family (43, 44). It is synthetized as an inactive precursor, which requires the removal of 20 aminoacids of the C-terminus for its activation (45). This processing event is believed to unmask the perforin C2 domain, enabling it to bind to the cell membrane (45). Perforin is essential for the entry of granzymes into the cells and in vitro experiments have shown that loss of perforin leads to complete failure of effector cells to lyse targets $(46,47)$. Furthermore, perforin-deficient mice are susceptible to numerous immunogenic challenges that are normally eliminated by cytotoxic cells $(46,48)$. In human beings, perforin deficiency has been shown to be the underlying mechanism in the development of familial hemophagocytic lymphohistiocytosis (HLH) pathogenesis, since $30-40 \%$ of such patients have mutations in both copies of the perforin gene, leading to complete loss of function (49). As a consequence, they develop severe immunoregulatory disorder in infancy (49).

Granzymes belong to a family of neutral serine proteases. Seven different granzymes have been identified in the mouse (granzymes A-G) $(50,51)$ and five in human beings (granzymes A, B, H, M, and K) (52-54). All five human granzymes have been shown to initiate caspase-dependent or independent cell death (55). The most abundant and the most studied are granzymes A and B (33). Granzymes $\mathrm{H}$ and $\mathrm{M}$ are preferentially expressed by NK cells (52, 56 ), while granzyme $\mathrm{K}$ is more restricted to lymphocytes of the $\mathrm{T}$ cell lineage $(53,54)$. All granzymes are initially synthesized as zymogens, being finally converted into active enzymes inside secretory granules by cleavage of the dipeptide (usually Gly-Glu or Glu-Glu) from their $\mathrm{N}$ terminus (57). The granzymes differ in their substrate specificity and cleave distinct target cell proteins to initiate apoptosis (58-60). While complete loss of exocytosisdependent cytotoxicity is documented in perforin-deficient mice, a milder deficiency has been observed in individual granzyme gene-knockout animals, suggesting that a redundancy of function between individual granzymes with regard to viral infections and tumor control (61-64).

Other, non-cytotoxic roles of granzymes have recently been detected. Granzyme A has been shown to promote release of proinflamatory cytokines, such as IL- $1 \beta$ from primary mouse macrophages (65) while granzyme B can cleave many extracellular matrix (ECM) components, thus, promoting detachment-induced cell death, or anoikis (66). In addition, granzyme B is involved in regulating the function and maintenance of $\mathrm{T}$ helper cell populations (67), and the direct cleavage of viral proteins (68).

\section{NATURAL KILLER CELLS}

Natural killer cells constitute only $10 \%$ of lymphocytes. However, they are major cytotoxic effectors of innate immune responses toward pathogens, most notably viruses (69) and transformed and senescent cells $(70,71)$. In human beings, NK cells develop from $\mathrm{CD}^{+}{ }^{+}$hematopoietic cells in the bone marrow and undergo terminal maturation in secondary lymphoid tissues (72). On the basis of surface CD56 expression, two major subsets of NK cells can be distinguished in human peripheral blood, namely, CD56 ${ }^{\mathrm{dim}}$ and CD56 ${ }^{\text {bright }} \mathrm{NK}$ cells (72). CD56 ${ }^{\text {dim }} \mathrm{NK}$ cells are the predominant mediators of the cytotoxicity response. They are fully mature, and constitute $90 \%$ of the NK cells in peripheral blood, while CD56 $6^{\text {bright }}$ cells are immature-like, and have been considered primarily as cytokine producers (73).

Natural killer cells are independent of antigen presentation (74). Their activation is inhibited through the interaction of their inhibitory receptors with MHC class I molecules (75), which are expressed on nearly every healthy cell of the body (76). Although it was initially thought that NK cell activation is triggered only by the lack of interaction with MHC class I molecules (76), further studies have revealed that it is a more complex process, involving a number of structurally distinct germline-encoded receptors (77). Activation receptors can be grouped, according to their signaling pathways, in three categories: those that signal through immunoreceptor tyrosine-based activation motif (ITAM)-containing subunits (e.g., CD16, NKp46, NKp44), through the DAP10-associated receptor NKG2D, and through other receptors (e.g., CD2, 2B4, DNAM-1) that signal by different pathways. These receptors usually synergize to activate NK cells, so the activation in their recognition of a target is achieved after a favorable balance of activation over inhibitory signals $(78,79)$.

Since NK cells exist in a "pre-activated" state (74) and are capable of secreting cytotoxic granules almost immediately upon activation (80), multiple checkpoints are in place to avoid inappropriate degranulation and damage to healthy cells $(81,82)$. In addition, the granule polarization and degranulation arising from NK cell activation are under the control of different activation pathways [reviewed in Ref. (79)].

Apart from their cytolytic function, NK cells contribute significantly to the cytokine milieu, and their release upon activation can significantly modulate the subsequent adaptive immune response. More precisely, it has been shown that NK cells can stimulate $\mathrm{T}$ cell responses to a variety of antigens, by cytokine and chemokine production directly or indirectly, by acting on antigen presenting cells (APCs) $(83,84)$. Furthermore, in interaction with stem cells and some tumor cells, NK cells almost completely lose their ability to mediate cytotoxicity but secrete significant amounts of cytokines - a condition termed split anergy (85). NK cells with split anergy may be involved in regulating the differentiation and resistance of a variety of stem cells, including cancer stem cells (86). Furthermore, NK cells can kill activated T cells and APCs directly (87-89). Their ability to dampen an immune response may provide protection in the context of autoimmunity $(87,90)$. 
In addition, new evidence indicates that NK cells can be "educated" and selected during development and that they exhibit antigen specificity and undergoes clonal expansion during infection $(91,92)$. On a mouse model of cytomegalovirus (CMV) infection, long-lived NK cells have been shown to arise under certain circumstances (91). Furthermore, a population of longlived NK cells exhibiting enhanced responsiveness to secondary CMV infection was detected in certain human transplant recipients $(93,94)$. All these newly gained attributes, usually assigned to the components of the adaptive immune system, give rise to a new dimension in the role of NK cells in the immune response.

\section{CYTOTOXIC T CELLS}

In general, initial recognition of pathogen infected or transformed cells by the components of innate immunity is followed by the adaptive immune response that is mediated by clonally selected and expanded antigen-specific CTLs.

Cytotoxic T lymphocytes develop in the thymus from a common lymphoid progenitor, through a series of distinct developmental stages that lead to the generation of fully competent, selfMHC I complex restricted, naive $\mathrm{CD}^{+} \mathrm{T}$ cells (95). Naive CD8 ${ }^{+}$ $\mathrm{T}$ cells are small round cells that do not contain cytotoxic granules (96-98). For their full development into effector cells capable of cytotoxic killing, CTLs require appropriate antigen stimulation. The $\mathrm{T}$ cell receptor (TCR) serves as the antigen receptor of $\mathrm{CD}^{+} \mathrm{T}$ cells. It recognizes an antigenic peptide presented within the antigen-binding groove of a particular MHC class I molecule itself presented on the surface of professional APC, namely, dendritic cells (99). In order to become fully activated and undergo clonal expansion, CTLs cells need to receive a co-stimulatory signal provided by interactions of T cell-specific CD28 molecules with their APC-expressed glycoprotein ligands B7.1 (CD80) and B7.2 (CD86) (100). Appropriate activation triggers synthesis of the lytic proteins in CTLs (98), cell division, and the appearance of fully differentiated, electron-dense cytotoxic granules in the cytoplasm $(96,97)$. Further recognition of target cells via the TCR on these activated cells triggers polarized movement of cytotoxic granules to the specialized area called the cytolytic synapse and to exocytosis of their contents into the extracellular space (101). This process also reinitiates the cycle of protein synthesis and organelle biogenesis, allowing further rounds of killing to take place (102).

It is important to emphasize that, apart from $\mathrm{CD}^{+} \mathrm{T}$ lymphocytes, human $\mathrm{CD} 4^{+} \mathrm{T}$ regulatory cells (Tregs) have recently also been shown to express components of cytotoxic machinery and to kill autologous and allogeneic target cells, including activated $\mathrm{CD}^{+}{ }^{+}$and $\mathrm{CD} 8^{+} \mathrm{T}$ cells, B-cells, monocytes, and both immature and mature dendritic cells, in a perforin- and/or granzyme-dependent manner (103-105). These data emphasize the importance of the cytotoxic death pathway mediated by perforin and granzymes, not only for effective clearance of infections and immune surveillance but also for down regulation of the immune response, maintenance of lymphocyte homeostasis, and prevention of autoimmune diseases.

\section{CYSTEINE CATHEPSINS IN THE IMMUNE RESPONSE}

Cysteine cathepsins can be divided into those constitutively expressed in cells and tissues, and those found predominantly in specific cell types. Constitutively expressed cathepsins, such as cathepsins B, L, and $\mathrm{H}$, are present in most immune cells, the highest levels being found in macrophages (106). Specific expression of cathepsin $\mathrm{C}$ has been observed in CTLs, macrophages, and granulocytes and mast cells $(107,108)$, of cathepsin X in monocytes, macrophages, dendritic cells, and T cells (32), of cathepsin S in APCs such as dendritic cells, B-cells, and macrophages (109), of cathepsin $\mathrm{F}$ in macrophages (7), and of cathepsin W (also known as lymphopain) in NK cells (110).

The most investigated role of cysteine cathepsins in the immune response is the regulation of MHC class II-dependent antigen presentation (5). This process requires the participation of cysteine cathepsins in two convergent processes: degradation of antigen into antigenic peptides and stepwise degradation of invariant chain (Ii), which blocks MHC class II molecule peptide binding site, to class II-associated invariant chain peptide (CLIP). Cathepsins $\mathrm{S}$ and $\mathrm{L}$ have been suggested as the key enzymes involved in the processing of Ii. Cathepsin S appears to be essential for removal of Ii in B-cells and dendritic cells, whereas this function is carried out by cathepsin L in thymic epithelial cells (111). In macrophages, both enzymes are present (111). Accordingly, the absence of cathepsins $\mathrm{S}$ and $\mathrm{L}$ has major consequences for the onset of the $\mathrm{T}$ cell dependent immune response. When cathep$\sin \mathrm{S}$ is missing, the processing of Ii is stopped at p10 fragment and the transport of MHC class II to the cell surface is delayed by its strong retention in lysosomes (112). Similarly, cathepsin L-deficient mice exhibit abnormalities in positive thymic selection due to the accumulation of p10 Ii fragment and defective MHC class II peptide loading in thymic epithelial cells $(106,112)$. Cathepsin $\mathrm{F}$ is another cysteine cathepsin involved in Ii processing in macrophages (7). The different $\mathrm{pH}$ profiles of cathepsins $\mathrm{F}$ and $\mathrm{S}$ suggest that the possibility that they may function in distinct antigen processing compartments. The $\mathrm{pH}$ optimum of cathep$\sin \mathrm{F}$ favors lysosomes, whereas cathepsin $\mathrm{S}$ activity is present throughout the endosomal/lysosomal pathway.

Cathepsin $\mathrm{X}$ expression is restricted to cells of the immune system, predominantly monocytes, macrophages, microglia, and dendritic cells $(113,114)$. It acts solely as an exopeptidase and regulates the proliferation, maturation, migration, and adhesion of immune cells, as well as their phagocytosis and signal transduction (8), and therefore, could indirectly affect the function of cytotoxic cells. Recently, several molecular targets of cathepsin X exopeptidase activity have been identified, including integrin receptors, $\gamma$-enolase, chemokine CXCL-12, bradykinin, kallidin, huntingtin, and profilin 1 [reviewed in Ref. (32)]. Of these, the interactions with integrin receptors appear to be the most relevant for cathepsin $\mathrm{X}$ function in immune cells. Active cathepsin $\mathrm{X}$ cleaves sequentially four C-terminal amino acids of the $\beta 2$ subunit of the $\beta 2$ integrin receptors that are present predominantly in cells of monocyte/macrophage lineage (115). In monocytes and macrophages, this cleavage results in activation of the $\beta 2$ integrin receptor Mac1 (CD11b/CD18) that is associated with increased cell adhesion, phagocytosis, and $\mathrm{T}$ lymphocyte activation. In addition, the Mac1 receptor is crucial for the functioning of dendritic cells, and its recruitment accompanies the adhesion of immature dendritic cells to the ECM. During maturation, cathepsin X translocates to the plasma membrane of maturing dendritic cells, enabling Mac-1 
activation and, consequently, cell adhesion. In mature dendritic cells, cathepsin $\mathrm{X}$ is redistributed from the plasma membrane back to the perinuclear region, which coincides with the detachment of dendritic cells and acquisition of the mature phenotype (116). In addition to active cathepsin $\mathrm{X}$, its pro-form may also iteract with integrin receptors through RGD (Arg-Gly-Asp) motifs present in its propeptide $(117,118)$. By binding to integrin receptors such as $\alpha v \beta 3$ and $\alpha v \beta 5$ that bind RGD, cathepsin $\mathrm{X}$ significantly changes cell adhesion to the proteins of ECM (119).

Besides in macrophage/dendritic cell lineages, cathepsin $\mathrm{X}$ is present also in T cells (120), although in lower levels (Figure 1). In $T$ cells, cathepsin $X$ regulates the function of another $\beta 2$ integrin receptor-lymphocyte function associated antigen-1 (LFA-1). LFA-1 is one of the key regulators of physiological T cell functions, including migration and formation of the immunological synapse. The interaction of cathepsin X with LFA-1 promotes cytoskeletondependent morphological changes and migration. Gradual cleavage of the $\beta 2$ cytoplasmic tail of LFA- 1 modulates its affinity for the structural adaptors talin- 1 and $\alpha$-actinin- 1 , enabling a stepwise transition between intermediate and high-affinity conformations of LFA-1 (121). Conformational changes are of vital importance for the regulation of LFA-1 affinity and the binding of ICAM-1. LFA- 1 fine-tuning by cathepsin X enables the trafficking of T cells, which is accompanied by extensive actin remodeling via selective binding of actin by talin- 1 and $\alpha$-actinin- 1 .

Cathepsin $\mathrm{X}$ and other cysteine cathepsins ( $\mathrm{B}, \mathrm{K}$, and $\mathrm{S}$ ) are expressed also in microglia (122). It is now clear that activation of microglia contributes to neurodegeneration by releasing neurotrophic factors. These act as neuroprotective, proinflammatory, and/or cytotoxic factors that contribute to the degeneration of neurons (123). Cathepsin X secreted from microglia may affect $\gamma$ enolase, one of the neurotrophic factors present in neurons, by proteolytic cleavage of its C-terminus (9).

Cathepsin C is expressed mainly in cytotoxic cells, mast cells, and neutrophils. Its predominant localization in the secretory granule compartment of these cells is suggestive of its specific function. Thus, cathepsin $\mathrm{C}$ has been shown to be indispensable for processing neutrophil serine proteases (granzymes, cathepsin G, and elastase) (124). Accordingly, patients suffering from Papillon-Lefèvre syndrome, characterized by congenital cathepsin C deficiency, exhibit manifestations of neutrophil dysfunction, such as severe gingivitis $(125,126)$. Furthermore, cathepsin $\mathrm{C}$ has been shown to be necessary for activating mast cell chymases in mice (127).

Cathepsin W is expressed predominantly in NK cells and is up-regulated by IL-2, but not IL-12. NK cells contain, on average, 21 times more cathepsin W mRNA transcript than CTLs, whereas $\mathrm{CD}^{+} \mathrm{T}$ lymphocytes contain only traces. However, cathepsin $\mathrm{W}$ protein is not localized in secretory granules, like cathepsins $\mathrm{C}$ and $\mathrm{H}$, but mainly in the endoplasmic reticulum, suggesting that it is not involved in pro-granzyme processing but rather plays a role in ER-resident proteolytic machinery (128).

Cysteine cathepsins have also been considered as an important element for protecting cytotoxic cells from their cytotoxic cargo (129). Thus, acidic conditions in cytotoxic granules inhibit granzyme activity and disable calcium binding to perforin, which is required for its activity (6). However, as cytotoxic cells are

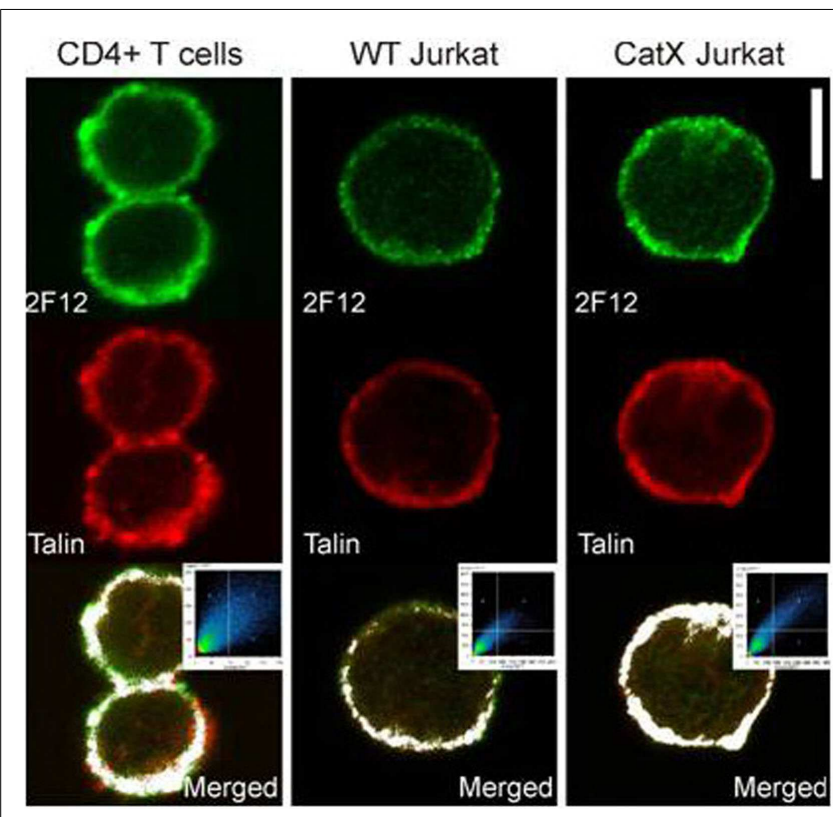

FIGURE 1 | Colocalization of cathepsin $\mathrm{X}$ and adaptor protein talin-1 in T cells (120). Primary CD4 ${ }^{+} T$ cells, Jurkat cells, and cathepsin $\mathrm{X}$-overexpressing Jurkat cells were allowed to migrate on ICAM-1precoated slides for $30 \mathrm{~min}$, and analyzed for colocalization of talin and cathepsin X. Specific antibodies for talin-1 (red) and cathepsin X (2F12, green) have been applied. The threshold level for this display corresponds to one-third of the maximal brightness level. Colocalization is represented by the pixels above the threshold in both channels on the contour plot and on the merged image (white color). Original scale bar, $5 \mu \mathrm{m}$.

able to kill target cells in vitro, it is unclear how they are protected from the toxic effects of their granules, particularly perforin following its release into the cytolytic synapse. Balaji and collaborators suggested that cathepsin B might serve as a specific inhibitor of perforin following degranulation (129). However, CTLs from cathepsin B deficient mice were later shown to exhibit cytotoxic efficiency and survival on encounter with targets comparable to those of wild-type CTLs, questioning the role of cathepsin B in perforin inactivation (130).

Cathepsin K, expressed predominately in osteoclasts and involved in bone remodeling processes, also exists in immune cells, i.e., in cytoplasmic granules of multinucleated giant cells and in epithelioid cells, but not in normal resident macrophages (131). It has been implicated in the activation of dentritic cells and in contributing to autoimmune inflammatory processes (132).

\section{REGULATION OF CELL CYTOTOXICITY BY CYSTEINE CATHEPSINS AND THEIR INHIBITORS}

Predominant expression of particular cathepsins in cytotoxic cells and their subcellular localization, as well as their substrate specificity, make them likely candidates for the activation of cytotoxic zymogens. As noted earlier, perforin and granzymes require C(perforin) or $\mathrm{N}$ - (granzymes) terminal processing in order to become activated and this activation was suggested to be accomplished by cysteine cathepsins. However, even though it has been shown in vitro that cathepsin $\mathrm{L}$ can process the $\mathrm{C}$-terminal part 
of perforin and that its inhibition impairs cytotoxicity of human NK cell lines and mouse primary CTLs, ex vivo experiments on CTLs and NK cells from cathepsin L-deficient mice showed no difference in the effectiveness of target cell killing from that of controls (133), indicating that there are other proteases involved in this process. Cathepsin $\mathrm{C}$ has been proposed as the main protease to generate active granzymes from their precursor forms by proteolytic cleavage of the N-terminal dipeptide (134). However, the lymphocytes from cathepsin C-null mice express reduced, but still adequate, granzyme B activity and kill target cells almost as effectively as wild-type mice (135). In addition, lymphocytes derived from patients with Papillon-Lefevre syndrome contain active granzyme B and kill target cells as effectively as healthy controls (125). Thus, at least for granzyme B, an alternative mechanism for processing and activation was proposed. Cathepsin $\mathrm{H}$ has been suggested as an alternative pro-granzyme B convertase; however, lymphocytes deficient in both cathepsin $\mathrm{C}$ and $\mathrm{H}$ are still able to generate active granzyme $\mathrm{B}$, indicating that the involvement of other enzymes in pro-granzyme processing (42). Thus, based on current knowledge, functional redundancy in the activation of both granzymes and perforin could be an important adaptation in preventing tumor or pathogen-mediated immune suppression by inhibition of a single protease.

As in other cells, the activity of cysteine cathepsins in immune cells is controlled by endogenous cysteine protease inhibitors. Type I cystatin stefin A (also known as cystatin A) is present in follicular dendritic cells, in Hassall's corpuscles and in thymic medullary cells, but not in lymphocytes (136). Macrophages contain stefin B (also known as cystatin B) and secrete it into the cell culture medium, while peripheral blood monocytes exhibit no stefin B immunoreactivity (137). The type II cystatins most abundant in immune cells are cystatin $\mathrm{C}$ and cystatin $\mathrm{F}$ (also known as leukocystatin and CST7). Cystatin C content was found to be higher in immature dendritic cells than in monocytes, promonocyte U937 cells, and mature dendritic cells. The secretion of cystatin C from immature dendritic cells is in line with their strong endocytic activity and is decreased during maturation, in keeping with abolished endocytosis (109).

Cystatin $\mathrm{F}$ is an exception among cystatins. After its synthesis, it is translocated to endosomes/lysosomes and is able to regulate cathepsin activity in these vesicles (138). It is predominantly expressed in lymphoid cells, with a preference for T cells, monocytes, NK cells, and dendritic cells. Cystatin F is produced in cells as a disulfide-linked dimer (139) inactive as an inhibitor of the C1 family of cysteine proteases (138). In vitro, unusually strong reducing conditions are needed to dissociate dimer to monomer. However, truncation of its N-terminal region, presumably by cathepsin V (also known as cathepsin L2/U) (140) (Figure 2), significantly enhances the monomerization and also changes the inhibitory properties of the resulting monomer (141). Intact monomeric cystatin $\mathrm{F}$ binds tightly to cysteine endopeptidases such as cathepsins L, F, K, and V, less tightly to cathepsins $\mathrm{S}$ and $\mathrm{H}$, but not to exopeptidases cathepsins $\mathrm{B}, \mathrm{X}$, and $\mathrm{C}$ (138, 142, 143). Cystatin F, following N-terminal truncation, is a strong inhibitor of cathepsin C (141) but a weaker inhibitor of cathep$\sin \mathrm{S}$, whereas its ability to inhibit cathepsin $\mathrm{H}$ is only slightly increased (144). In cytotoxic cells, cystatin F therefore appears

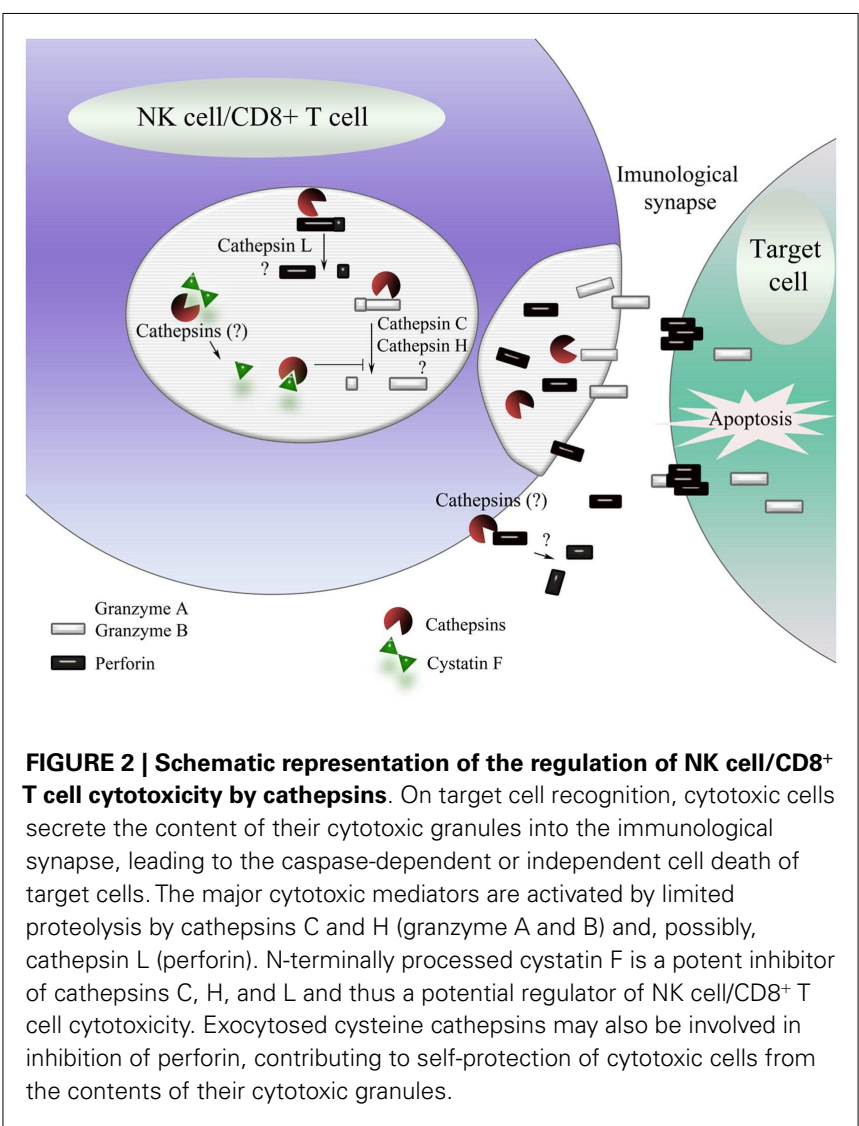

as a key regulator of granzyme processing and consequently cell cytotoxicity (Figure 2).

\section{CONCLUSION}

Cysteine cathepsins are important players in the multiple processes of the immune response. Traditionally, these enzymes have been believed to execute proteolysis non-selectively within the lysosomes, to be redundant in their substrate specificity and to be expressed ubiquitously in cells and tissues. However, recently, this view has changed since restricted expression and specific enzymatic activity have been discovered for some of them. The role of cysteine cathepsins in CTLs and NK cells is particularly notable, since the ability of cathepsin $\mathrm{C}$ and cathepsin $\mathrm{H}$ to activate progranzymes in secretory granules is directly linked to the initiation of caspase-dependent or independent death of their target cells. Furthermore, cysteine cathepsins, like cathepsin L, can activate perforin, another key player in the cytotoxic process. Owing to their important role in cytotoxicity, the activity of cysteine cathepsins has to be precisely regulated. For that role, cystatin F, as the only endogenous cysteine protease inhibitor localized in endoso$\mathrm{mal} /$ lysosomal vesicles, is a good candidate. Furthermore, since its activity is also regulated by proteolytic cleavage of its $\mathrm{N}$-terminal peptide by, supposedly, cathepsin $\mathrm{V}$, the latter may control the inhibitory activity of cystatin $\mathrm{F}$ and, hence, the rate of inhibition of pro-granzyme convertases cathepsins $\mathrm{C}$ and $\mathrm{H}$. Owing to the specific roles of cathepsins $\mathrm{C}, \mathrm{H}$, and $\mathrm{V}$ and cystatin $\mathrm{F}$ in regulating cell cytotoxicity, they are potential therapeutic targets 
for improving cell therapy or impairing cytotoxicity in immune disorders. Future work therefore needs to be focused on understanding the fine-tuning in the cytotoxicity regulatory network, thus, enabling specific targets for immunotherapy to be identified.

\section{REFERENCES}

1. Rawlings ND, Barrett AJ, Bateman A. MEROPS: the database of proteolytic enzymes, their substrates and inhibitors. Nucleic Acids Res (2012) 40:D343-50. doi:10.1093/nar/gkr987

2. Turk B. Targeting proteases: successes, failures and future prospects. Nat Rev Drug Discov (2006) 5:785-99. doi:10.1038/nrd2092

3. Turk V, Stoka V, Vasiljeva O, Renko M, Sun T, Turk B, et al. Cysteine cathepsins: from structure, function and regulation to new frontiers. Biochim Biophys Acta (2012) 1824:68-88. doi:10.1016/j.bbapap.2011.10.002

4. Kopitar-Jerala N. The role of cysteine proteinases and their inhibitors in the host-pathogen cross talk. Curr Protein Pept Sci (2012) 13:767-75. doi:10.2174/ 138920312804871102

5. Obermajer N, Doljak B, Kos J. Cysteine cathepsins: regulators of antitumour immune response. Expert Opin Biol Ther (2006) 6:1295-309. doi:10.1517/ 14712598.6.12.1295

6. Bird PI, Trapani JA, Villadangos JA. Endolysosomal proteases and their inhibitors in immunity. Nat Rev Immunol (2009) 9:871-82. doi:10.1038/ nri2671

7. Shi GP, Bryant RA, Riese R, Verhelst S, Driessen C, Li Z, et al. Role for cathepsin $\mathrm{F}$ in invariant chain processing and major histocompatibility complex class II peptide loading by macrophages. J Exp Med (2000) 191:1177-86. doi:10.1084/jem.191.7.1177

8. Kos J, Jevnikar Z, Obermajer N. The role of cathepsin X in cell signaling. Cell Adh Migr (2009) 3:164-6. doi:10.4161/cam.3.2.7403

9. Hafner A, Glavan G, Obermajer N, Zivin M, Schliebs R, Kos J. Neuroprotective role of gamma-enolase in microglia in a mouse model of Alzheimer's disease is regulated by cathepsin X. Aging Cell (2013) 12:604-14. doi:10.1111/acel.12093

10. Roberts R. Lysosomal cysteine proteases: structure, function and inhibition of cathepsins. Drug News Perspect (2005) 18:605-14. doi:10.1358/dnp.2005.18. 10.949485

11. Turk V, Turk B, Turk D. Lysosomal cysteine proteases: facts and opportunities. EMBO J (2001) 20:4629-33. doi:10.1093/emboj/20.17.4629

12. Turk D, Guncar G, Podobnik M, Turk B. Revised definition of substrate binding sites of papain-like cysteine proteases. Biol Chem (1998) 379:137-47. doi:10.1515/bchm.1998.379.2.137

13. Turk D, Guncar G. Lysosomal cysteine proteases (cathepsins): promising drug targets. Acta Crystallogr D Biol Crystallogr (2003) 59:203-13. doi:10.1107/ S0907444902021479

14. Musil D, Zucic D, Turk D, Engh RA I, Mayr R, Huber T, et al. The refined 2.15 A X-ray crystal structure of human liver cathepsin B: the structural basis for its specificity. EMBO J (1991) 10:2321-30.

15. Therrien C, Lachance P, Sulea T, Purisima EO, Qi H, Ziomek E, et al. Cathepsins $\mathrm{X}$ and $\mathrm{B}$ can be differentiated through their respective monoand dipeptidyl carboxypeptidase activities. Biochemistry (2001) 40:2702-11. doi:10.1021/bi002460a

16. Guncar G, Podobnik M, Pungercar J, Strukelj B, Turk V, Turk D. Crystal structure of porcine cathepsin $\mathrm{H}$ determined at 2.1 A resolution: location of the mini-chain C-terminal carboxyl group defines cathepsin $\mathrm{H}$ aminopeptidase function. Structure (1998) 6:51-61. doi:10.1016/S0969-2126(98)00007-0

17. Barrett AJ, Kirschke H. Cathepsin B, Cathepsin H, and cathepsin L. Methods Enzymol (1981) 80(Pt C):535-61.

18. Vasiljeva O, Dolinar M, Turk V, Turk B. Recombinant human cathepsin H lacking the mini chain is an endopeptidase. Biochemistry (2003) 42:13522-8. doi:10.1021/bi035355k

19. Karrer KM, Peiffer SL, DiTomas ME. Two distinct gene subfamilies within the family of cysteine protease genes. Proc Natl Acad Sci U S A (1993) 90:3063-7. doi:10.1073/pnas.90.7.3063

20. Novinec M, Lenarcic B. Cathepsin K: a unique collagenolytic cysteine peptidase. Biol Chem (2013) 394:1163-79. doi:10.1515/hsz-2013-0134

21. Turk V, Kos J, Turk B. Cysteine cathepsins (proteases) - on the main stage of cancer? Cancer Cell (2004) 5:409-10. doi:10.1016/S1535-6108(04)00117-5

22. Dubin G. Proteinaceous cysteine protease inhibitors. Cell Mol Life Sci (2005) 62:653-69. doi:10.1007/s00018-004-4445-9
23. Keppler D. Towards novel anti-cancer strategies based on cystatin function. Cancer Lett (2006) 235:159-76. doi:10.1016/j.canlet.2005.04.001

24. Abrahamson M, Barrett AJ, Salvesen G, Grubb A. Isolation of six cysteine proteinase inhibitors from human urine. Their physicochemical and enzyme kinetic properties and concentrations in biological fluids. J Biol Chem (1986) 261:11282-9.

25. Abrahamson M, Alvarez-Fernandez M, Nathanson CM. Cystatins. Biochem Soc Symp (2003) 70:179-99.

26. Bode W, Engh R, Musil D, Thiele U, Huber R, Karshikov A, et al. The 2.0 A $\mathrm{X}$-ray crystal structure of chicken egg white cystatin and its possible mode of interaction with cysteine proteinases. EMBO J (1988) 7:2593-9.

27. Alvarez-Fernandez M, Barrett AJ, Gerhartz B, Dando PM, Ni J, Abrahamson M. Inhibition of mammalian legumain by some cystatins is due to a novel second reactive site. J Biol Chem (1999) 274:19195-203. doi:10.1074/jbc.274. 27.19195

28. Colbert JD, Matthews SP, Kos J, Watts C. Internalization of exogenous cystatin $\mathrm{F}$ supresses cysteine proteases and induces the accumulation of singlechain cathepsin L by multiple mechanisms. J Biol Chem (2011) 286:42082-90. doi:10.1074/jbc.M111.253914

29. Wallin H, Abrahamson M, Ekstrom U. Cystatin C properties crucial for uptake and inhibition of intracellular target enzymes. J Biol Chem (2013) 288:17019-29. doi:10.1074/jbc.M113.453449

30. Hanada K, Tamai M, Yamagishi M, Ohmura S, Sawada J, Tanaka I. Isolation and characterization of E 64, a new thiol protease inhibitor. Agric Biol Chem (1978) 42:523-8. doi:10.1271/bbb1961.42.523

31. Murata M, Miyashita S, Yokoo C, Tamai M, Hanada K, Hatayama K, et al. Novel epoxysuccinyl peptides. Selective inhibitors of cathepsin B, in vitro. FEBS Lett (1991) 280:307-10. doi:10.1016/0014-5793(91)80318-W

32. Kos FJ, Mitrovic A, Mirkovic B. The current stage of cathepsin B inhibitors as potential anti-cancer agents. Future Med Chem (2014) 6:1335-71. doi:10.4155/ fmc. 14.73

33. Russell JH, Ley TJ. Lymphocyte-mediated cytotoxicity. Annu Rev Immunol (2002) 20:323-70. doi:10.1146/annurev.immunol.20.100201.131730

34. Mullbacher A, Waring P, Tha Hla R, Tran T, Chin S, Stehle T, et al. Granzymes are the essential downstream effector molecules for the control of primary virus infections by cytolytic leukocytes. Proc Natl Acad Sci U S A (1999) 96:13950-5. doi:10.1073/pnas.96.24.13950

35. van Dommelen SL, Sumaria RD, Fau-Schreiber N, Schreiber AA, Fau-Scalzo $\mathrm{RD}$, Scalzo MJ, et al. Perforin and granzymes have distinct roles in defensive immunity and immunopathology. Immunity (2006) 25:835-48.

36. Trapani JA, Smyth MJ. Functional significance of the perforin/granzyme cell death pathway. Nat Rev Immunol (2002) 2:735-47. doi:10.1038/nri911

37. Hayakawa Y, Kelly JM, Westwood JA, Darcy PK, Diefenbach A, Raulet D, et al. Cutting edge: tumor rejection mediated by NKG2D receptor-ligand interaction is dependent upon perforin. J Immunol (2002) 169:5377-81. doi:10.4049/jimmunol.169.10.5377

38. Graubert TA, DiPersio JF, Russell JH, Ley TJ. Perforin/granzyme-dependent and independent mechanisms are both important for the development of graftversus-host disease after murine bone marrow transplantation. J Clin Invest (1997) 100:904-11. doi:10.1172/JCI119606

39. Burkhardt JK, Hester S, Lapham CK, Argon Y. The lytic granules of natural killer cells are dual-function organelles combining secretory and pre-lysosomal compartments. J Cell Biol (1990) 111:2327-40. doi:10.1083/jcb.111.6.2327

40. Peters PJ, Borst J, Oorschot V, Fukuda M, Krahenbuhl O, Tschopp J, et al. Cytotoxic T lymphocyte granules are secretory lysosomes, containing both perforin and granzymes. J Exp Med (1991) 173:1099-109. doi:10.1084/jem.173.5.1099

41. Blott EJ, Griffiths GM. Secretory lysosomes. Nat Rev Mol Cell Biol (2002) 3:122-31. doi:10.1038/nrm732

42. D’Angelo ME, Bird PI, Peters C, Reinheckel T, Trapani JA, Sutton VR. Cathep$\sin \mathrm{H}$ is an additional convertase of pro-granzyme B. J Biol Chem (2010) 285:20514-9. doi:10.1074/jbc.M109.094573

43. Shinkai Y, Takio K, Okumura K. Homology of perforin to the ninth component of complement (C9). Nature (1988) 334:525-7. doi:10.1038/334525a0

44. Voskoboinik I, Smyth MJ, Trapani JA. Perforin-mediated target-cell death and immune homeostasis. Nat Rev Immunol (2006) 6:940-52. doi:10.1038/ nri1983

45. Uellner R, Zvelebil J, Fau-Hopkins MJ, Hopkins J, Fau-Jones J, Jones LK, et al. Perforin is activated by a proteolytic cleavage during biosynthesis which reveals a phospholipid-binding C2 domain. EMBO J (1997) 16:7287-96. 
46. Kagi D, Ledermann K, Fau-Burki B, Burki P, Fau-Seiler K, Seiler B, et al. Cytotoxicity mediated by $\mathrm{T}$ cells and natural killer cells is greatly impaired in perforin-deficient mice. Nature (1994) 369:31-7.

47. Mouchacca P, Schmitt-Verhulst AM, Boyer C. Visualization of cytolytic T cell differentiation and granule exocytosis with $\mathrm{T}$ cells from mice expressing active fluorescent granzyme B. PLoS One (2013) 8:e67239. doi:10.1371/journal.pone. 0067239

48. van den Broek ME, Kagi D, Ossendorp F, Toes R, Vamvakas S, Lutz WK, et al. Decreased tumor surveillance in perforin-deficient mice. J Exp Med (1996) 184:1781-90. doi:10.1084/jem.184.5.1781

49. Stepp SE, Dufourcq-Lagelouse R, Le Deist F, Bhawan S, Certain S, Mathew PA, et al. Perforin gene defects in familial hemophagocytic lymphohistiocytosis. Science (1999) 286:1957-9. doi:10.1126/science.286.5446.1957

50. Jenne DE, Tschopp J. Granzymes, a family of serine proteases released from granules of cytolytic T lymphocytes upon T cell receptor stimulation. Immunol $\operatorname{Rev}$ (1988) 103:53-71. doi:10.1111/j.1600-065X.1988.tb00749.x

51. Jenne DE, Masson D, Zimmer M, Haefliger JA, Li WH, Tschopp J. Isolation and complete structure of the lymphocyte serine protease granzyme $\mathrm{G}$, a novel member of the granzyme multigene family in murine cytolytic T lymphocytes. Evolutionary origin of lymphocyte proteases. Biochemistry (1989) 28:7953-61.

52. Sedelies KA, Sayers TJ, Edwards KM, Chen W, Pellicci DG, Godfrey DI, et al. Discordant regulation of granzyme $\mathrm{H}$ and granzyme $\mathrm{B}$ expression in human lymphocytes. J Biol Chem (2004) 279:26581-7. doi:10.1074/jbc.M312481200

53. Bade B, Boettcher HE, Lohrmann J, Hink-Schauer C, Bratke K, Jenne DE, et al. Differential expression of the granzymes $\mathrm{A}, \mathrm{K}$ and $\mathrm{M}$ and perforin in human peripheral blood lymphocytes. Int Immunol (2005) 17:1419-28. doi:10.1093/intimm/dxh320

54. Bratke K, Kuepper M, Bade B, Virchow JC Jr, Luttmann W. Differential expression of human granzymes A, B, and $\mathrm{K}$ in natural killer cells and during CD8+ $\mathrm{T}$ cell differentiation in peripheral blood. Eur J Immunol (2005) 35:2608-16. doi:10.1002/eji.200526122

55. Chowdhury D, Lieberman J. Death by a thousand cuts: granzyme pathways of programmed cell death. Annu Rev Immunol (2008) 26:389-420. doi:10.1146/annurev.immunol.26.021607.090404

56. Sayers TJ, Brooks AD, Ward JM, Hoshino T, Bere WE, Wiegand GW, et al. The restricted expression of granzyme $\mathrm{M}$ in human lymphocytes. J Immunol (2001) 166:765-71. doi:10.4049/jimmunol.166.2.765

57. Caputo A, Garner RS, Winkler U, Hudig D, Bleackley RC. Activation of recombinant murine cytotoxic cell proteinase-1 requires deletion of an aminoterminal dipeptide. J Biol Chem (1993) 268:17672-5.

58. Trapani JA, Sutton VR. Granzyme B: pro-apoptotic, antiviral and antitumor functions. Curr Opin Immunol (2003) 15:533-43. doi:10.1016/S0952-7915(03) 00107-9

59. Thomas DA, Du C, Xu M, Wang X, Ley TJ. DFF45/ICAD can be directly processed by granzyme B during the induction of apoptosis. Immunity (2000) 12:621-32. doi:10.1016/S1074-7613(00)80213-7

60. Fan Z, Beresford PJ, Oh DY, Zhang D, Lieberman J. Tumor suppressor NM23$\mathrm{H} 1$ is a granzyme A-activated DNase during CTL-mediated apoptosis, and the nucleosome assembly protein SET is its inhibitor. Cell (2003) 112:659-72. doi:10.1016/S0092-8674(03)00150-8

61. Ebnet K, Hausmann M, Lehmann-Grube F, Mullbacher A, Kopf M, Lamers $\mathrm{M}$, et al. Granzyme A-deficient mice retain potent cell-mediated cytotoxicity. EMBO J (1995) 14:4230-9.

62. Simon MM, Hausmann M, Tran T, Ebnet K, Tschopp J, ThaHla R, et al. In vitroand ex vivo-derived cytolytic leukocytes from granzyme $\mathrm{A} x \mathrm{~B}$ double knockout mice are defective in granule-mediated apoptosis but not lysis of target cells. $J$ Exp Med (1997) 186:1781-6. doi:10.1084/jem.186.10.1781

63. Waterhouse NJ, Sutton KA, Fau-Sedelies VR, Sedelies A, Fau-Ciccone KA, Ciccone $\mathrm{M}$, et al. Cytotoxic T lymphocyte-induced killing in the absence of granzymes A and B is unique and distinct from both apoptosis and perforindependent lysis. J Cell Biol (2006) 173:133-44.

64. Pardo J, Bosque A, Brehm R, Wallich R, Naval J, Mullbacher A, et al. Apoptotic pathways are selectively activated by granzyme A and/or granzyme B in CTL-mediated target cell lysis. J Cell Biol (2004) 167:457-68. doi:10.1083/jcb. 200406115

65. Metkar SS, Menaa C, Pardo J, Wang B, Wallich R, Freudenberg M, et al. Human and mouse granzyme A induce a proinflammatory cytokine response. Immunity (2008) 29:720-33. doi:10.1016/j.immuni.2008.08.014
66. Buzza MS, Zamurs L, Sun J, Bird CH, Smith AI, Trapani JA, et al. Extracellular matrix remodeling by human granzyme B via cleavage of vitronectin, fibronectin, and laminin. J Biol Chem (2005) 280:23549-58. doi:10.1074/jbc. M412001200

67. Devadas S, Das J, Liu C, Zhang L, Roberts AI, Pan Z, et al. Granzyme B is critical for T cell receptor-induced cell death of type 2 helper T cells. Immunity (2006) 25:237-47. doi:10.1016/j.immuni.2006.06.011

68. Andrade F, Casciola-Rosen LA, Rosen A. A novel domain in adenovirus L4$100 \mathrm{~K}$ is required for stable binding and efficient inhibition of human granzyme B: possible interaction with a species-specific exosite. Mol Cell Biol (2003) 23:6315-26. doi:10.1128/MCB.23.17.6315-6326.2003

69. Jost S, Altfeld M. Control of human viral infections by natural killer cells. Annu Rev Immunol (2013) 31:163-94. doi:10.1146/annurev-immunol032712-100001

70. Smyth MJ, Hayakawa Y, Takeda K, Yagita H. New aspects of natural-killercell surveillance and therapy of cancer. Nat Rev Cancer (2002) 2:850-61. doi: $10.1038 / \mathrm{nrc} 928$

71. Sagiv A, Biran A, Yon M, Simon J, Lowe SW, Krizhanovsky V. Granule exocytosis mediates immune surveillance of senescent cells. Oncogene (2013) 32:1971-7. doi:10.1038/onc.2012.206

72. Caligiuri MA. Human natural killer cells. Blood (2008) 112:461-9. doi:10.1182/ blood-2007-09-077438

73. De Maria A, Bozzano F, Cantoni C, Moretta L. Revisiting human natural killer cell subset function revealed cytolytic CD56(dim)CD16+ NK cells as rapid producers of abundant IFN-gamma on activation. Proc Natl Acad Sci U S A (2011) 108:728-32. doi:10.1073/pnas.1012356108

74. Kos FJ, Engleman EG. Immune regulation: a critical link between NK cells and CTLs. Immunol Today (1996) 17:174-6. doi:10.1016/0167-5699(96)80616-5

75. Karre K. Natural killer cell recognition of missing self. Nat Immunol (2008) 9:477-80. doi:10.1038/ni0508-477

76. Ljunggren HG, Karre K. In search of the 'missing self': MHC molecules and NK cell recognition. Immunol Today (1990) 11:237-44. doi:10.1016/01675699(90)90097-S

77. Moretta L, Moretta A. Unravelling natural killer cell function: triggering and inhibitory human NK receptors. EMBO J (2004) 23:255-9. doi:10.1038/sj. emboj.7600019

78. Lanier LL. Up on the tightrope: natural killer cell activation and inhibition. Nat Immunol (2008) 9:495-502. doi:10.1038/ni1581

79. Long EO, Kim HS, Liu D, Peterson ME, Rajagopalan S. Controlling natural killer cell responses: integration of signals for activation and inhibition. Annu Rev Immunol (2013) 31:227-58. doi:10.1146/annurev-immunol-020711075005

80. Krzewski K, Strominger JL. The killer's kiss: the many functions of NK cell immunological synapses. Curr Opin Cell Biol (2008) 20:597-605. doi:10.1016/ j.ceb.2008.05.006

81. Freud AG, Caligiuri MA. Human natural killer cell development. Immunol Rev (2006) 214:56-72. doi:10.1111/j.1600-065X.2006.00451.x

82. Grzywacz B, Kataria N, Sikora M, Oostendorp RA, Dzierzak EA, Blazar BR, et al. Coordinated acquisition of inhibitory and activating receptors and functional properties by developing human natural killer cells. Blood (2006) 108:3824-33. doi:10.1182/blood-2006-04-020198

83. Walzer T, Dalod M, Robbins SH, Zitvogel L, Vivier E. Natural-killer cells and dendritic cells: "l'union fait la force". Blood (2005) 106:2252-8. doi:10.1182/ blood-2005-03-1154

84. Vankayalapati R, Klucar P, Wizel B, Weis SE, Samten B, Safi H, et al. NK cells regulate $\mathrm{CD} 8+\mathrm{T}$ cell effector function in response to an intracellular pathogen. J Immunol (2004) 172:130-7. doi:10.4049/jimmunol.172.1.130

85. Tseng HC, Arasteh A, Paranjpe A, Teruel A, Yang W, Behel A, et al. Increased lysis of stem cells but not their differentiated cells by natural killer cells; de-differentiation or reprogramming activates NK cells. PLoS One (2010) 5:e11590. doi:10.1371/journal.pone.0011590

86. Jewett A, Man YG, Cacalano N, Kos J, Tseng HC. Natural killer cells as effectors of selection and differentiation of stem cells: role in resolution of inflammation. J Immunotoxicol (2014) 11:297-307. doi:10.3109/1547691X.2013.877104

87. Bielekova B, Catalfamo M, Reichert-Scrivner S, Packer A, Cerna M, Waldmann TA, et al. Regulatory CD56(bright) natural killer cells mediate immunomodulatory effects of IL-2Ralpha-targeted therapy (daclizumab) in multiple sclerosis. Proc Natl Acad Sci U S A (2006) 103:5941-6. doi:10.1073/pnas.0601335103 
88. Rabinovich BA, Li J, Shannon J, Hurren R, Chalupny J, Cosman D, et al. Activated, but not resting, $\mathrm{T}$ cells can be recognized and killed by syngeneic NK cells. J Immunol (2003) 170:3572-6. doi:10.4049/jimmunol.170.7.3572

89. Orange JS. Formation and function of the lytic NK-cell immunological synapse. Nat Rev Immunol (2008) 8:713-25. doi:10.1038/nri2381

90. Jiang W, Chai NR, Maric D, Bielekova B. Unexpected role for granzyme K in CD56bright NK cell-mediated immunoregulation of multiple sclerosis. $J$ Immunol (2011) 187:781-90. doi:10.4049/jimmunol.1100789

91. Sun JC, Beilke JN, Lanier LL. Adaptive immune features of natural killer cells. Nature (2009) 457:557-61. doi:10.1038/nature07665

92. Vivier E, Raulet DH, Moretta A, Caligiuri MA, Zitvogel L, Lanier LL, et al. Innate or adaptive immunity? The example of natural killer cells. Science (2011) 331:44-9. doi:10.1126/science.1198687

93. Foley B, Cooley S, Verneris MR, Pitt M, Curtsinger J, Luo X, et al. Cytomegalovirus reactivation after allogeneic transplantation promotes a lasting increase in educated NKG2C+ natural killer cells with potent function. Blood (2012) 119:2665-74. doi:10.1182/blood-2011-10-386995

94. Lopez-Verges S, Milush JM, Schwartz BS, Pando MJ, Jarjoura J, York VA, et al. Expansion of a unique CD57(+)NKG2Chi natural killer cell subset during acute human cytomegalovirus infection. Proc Natl Acad Sci U S A (2011) 108:14725-32. doi:10.1073/pnas.1110900108

95. Abbey JL, O’Neill HC. Expression of T-cell receptor genes during early T-cell development. Immunol Cell Biol (2008) 86:166-74. doi:10.1038/sj.icb. 7100120

96. Olsen I, Bou-Gharios G, Abraham D. The activation of resting lymphocytes is accompanied by the biogenesis of lysosomal organelles. Eur J Immunol (1990) 20:2161-70. doi:10.1002/eji.1830201003

97. Bou-Gharios G, Moss J, Olsen I, Partridge T. Ultrastructural localization of a lysosomal enzyme in resin-embedded lymphocytes. Histochemistry (1988) 89:69-74. doi:10.1007/BF00496587

98. Podack ER, Kupfer A. T-cell effector functions: mechanisms for delivery of cytotoxicity and help. Annu Rev Cell Biol (1991) 7:479-504. doi:10.1146/annurev. cellbio.7.1.479

99. Wang JH, Reinherz EL. Structural basis of T cell recognition of peptides bound to MHC molecules. Mol Immunol (2002) 38:1039-49. doi:10.1016/S01615890(02)00033-0

100. Bour-Jordan H, Blueston JA. CD28 function: a balance of costimulatory and regulatory signals. J Clin Immunol (2002) 22:1-7. doi:10.1023/A: 1014256417651

101. Stinchcombe JC, Griffiths GM. Secretory mechanisms in cell-mediated cytotoxicity. Annu Rev Cell Dev Biol (2007) 23:495-517. doi:10.1146/annurev. cellbio.23.090506.123521

102. Isaaz S, Baetz K, Olsen K, Podack E, Griffiths GM. Serial killing by cytotoxic T lymphocytes: $T$ cell receptor triggers degranulation, re-filling of the lytic granules and secretion of lytic proteins via a non-granule pathway. Eur J Immunol (1995) 25:1071-9. doi:10.1002/eji.1830250432

103. Grossman WJ, Verbsky JW, Barchet W, Colonna M, Atkinson JP, Ley TJ. Human T regulatory cells can use the perforin pathway to cause autologous target cell death. Immunity (2004) 21:589-601. doi:10.1016/j.immuni.2004.09.002

104. Gondek DC, Lu LF, Quezada SA, Sakaguchi S, Noelle RJ. Cutting edge: contactmediated suppression by $\mathrm{CD} 4+\mathrm{CD} 25+$ regulatory cells involves a granzyme Bdependent, perforin-independent mechanism. J Immunol (2005) 174:1783-6. doi:10.4049/jimmunol.174.4.1783

105. Zhao DM, Thornton AM, DiPaolo RJ, Shevach EM. Activated CD4+CD25+ T cells selectively kill B lymphocytes. Blood (2006) 107:3925-32. doi:10.1182/ blood-2005-11-4502

106. Delamarre L, Pack M, Chang H, Mellman I, Trombetta ES. Differential lysosomal proteolysis in antigen-presenting cells determines antigen fate. Science (2005) 307:1630-4. doi:10.1126/science.1108003

107. Rao NV, Rao GV, Hoidal JR. Human dipeptidyl-peptidase I. Gene characterization, localization, and expression. J Biol Chem (1997) 272:10260-5. doi:10.1074/jbc.272.15.10260

108. Wolters PJ, Raymond WW, Blount JL, Caughey GH. Regulated expression, processing, and secretion of dog mast cell dipeptidyl peptidase I. J Biol Chem (1998) 273:15514-20. doi:10.1074/jbc.273.25.15514

109. Zavasnik-Bergant V, Sekirnik A, Golouh R, Turk V, Kos J. Immunochemical localisation of cathepsin S, cathepsin L and MHC class II-associated p41 isoform of invariant chain in human lymph node tissue. Biol Chem (2001) 382:799-804.

110. Stoeckle C, Gouttefangeas C, Hammer M, Weber E, Melms A, Tolosa E. Cathepsin $\mathrm{W}$ expressed exclusively in CD8+ T cells and NK cells, is secreted during target cell killing but is not essential for cytotoxicity in human CTLs. Exp Hematol (2009) 37:266-75. doi:10.1016/j.exphem.2008.10.011

111. Beers C, Honey K, Fink S, Forbush K, Rudensky A. Differential regulation of cathepsin $\mathrm{S}$ and cathepsin $\mathrm{L}$ in interferon gamma-treated macrophages. J Exp Med (2003) 197:169-79. doi:10.1084/jem.20020978

112. Shi GP, Villadangos JA, Dranoff G, Small C, Gu L, Haley KJ, et al. Cathepsin S required for normal MHC class II peptide loading and germinal center development. Immunity (1999) 10:197-206. doi:10.1016/S1074-7613(00)80020-5

113. Kos J, Sekirnik A, Premzl A, Zavasnik-Bergant V, Langerholc T, Turk B, et al. Carboxypeptidases cathepsins $\mathrm{X}$ and $\mathrm{B}$ display distinct protein profile in human cells and tissues. Exp Cell Res (2005) 306:103-13. doi:10.1016/j.yexcr. 2004.12.006

114. Pislar A, Kos J. Cysteine cathepsins in neurological disorders. Mol Neurobiol (2014) 49:1017-30. doi:10.1007/s12035-013-8576-6

115. Obermajer N, Premzl A, Zavasnik-Bergant T, Turk B, Kos J. Carboxypeptidase cathepsin X mediates beta2-integrin-dependent adhesion of differentiated U937 cells. Exp Cell Res (2006) 312:2515-27. doi:10.1016/j.yexcr.2006.04.019

116. Obermajer N, SVajger U, Bogyo M, Jeras M, Kos J. Maturation of dendritic cells depends on proteolytic cleavage by cathepsin X. J Leukoc Biol (2008) 84:1306-15. doi:10.1189/jlb.0508285

117. Santamaria I, Velasco G, Pendas AM, Fueyo A, Lopez-Otin C. Cathep$\sin \mathrm{Z}$, a novel human cysteine proteinase with a short propeptide domain and a unique chromosomal location. J Biol Chem (1998) 273:16816-23. doi:10.1074/jbc.273.27.16816

118. Nagler DK, Menard R. Human cathepsin X: a novel cysteine protease of the papain family with a very short proregion and unique insertions. FEBS Lett (1998) 434:135-9. doi:10.1016/S0014-5793(98)00964-8

119. Lechner AM, Assfalg-Machleidt I, Zahler S, Stoeckelhuber M, Machleidt W, Jochum M, et al. RGD-dependent binding of procathepsin X to integrin alphavbeta3 mediates cell-adhesive properties. J Biol Chem (2006) 281:39588-97. doi:10.1074/jbc.M513439200

120. Jevnikar Z, Obermajer N, Doljak B, Turk S, Gobec S, Svajger U, et al. Cathepsin $\mathrm{X}$ cleavage of the beta2 integrin regulates talin-binding and LFA-1 affinity in T cells. J Leukoc Biol (2011) 90:99-109. doi:10.1189/jlb.1110622

121. Jevnikar Z, Obermajer N, Kos J. LFA-1 fine-tuning by cathepsin X. IUBMB Life (2011) 63:686-93. doi:10.1002/iub.505

122. Wendt W, Schulten R, Stichel CC, Lubbert H. Intra- versus extracellular effects of microglia-derived cysteine proteases in a conditioned medium transfer model. J Neurochem (2009) 110:1931-41. doi:10.1111/j.1471-4159.2009. 06283.x

123. Block ML, Zecca L, Hong JS. Microglia-mediated neurotoxicity: uncovering the molecular mechanisms. Nat Rev Neurosci (2007) 8:57-69. doi:10.1038/nrn2038

124. Adkison AM, Raptis SZ, Kelley DG, Pham CT. Dipeptidyl peptidase I activates neutrophil-derived serine proteases and regulates the development of acute experimental arthritis. J Clin Invest (2002) 109:363-71. doi:10.1172/JCI13462

125. Pham CT, Ivanovich JL, Raptis SZ, Zehnbauer B, Ley TJ. Papillon-Lefevre syndrome: correlating the molecular, cellular, and clinical consequences of cathepsin C/dipeptidyl peptidase I deficiency in humans. J Immunol (2004) 173:7277-81. doi:10.4049/jimmunol.173.12.7277

126. de Haar SF, Jansen DC, Schoenmaker T, De Vree H, Everts V, Beertsen W. Lossof-function mutations in cathepsin $\mathrm{C}$ in two families with Papillon-Lefevre syndrome are associated with deficiency of serine proteinases in PMNs. Hum Mutat (2004) 23:524. doi:10.1002/humu.9243

127. Wolters PJ, Pham CT, Muilenburg DJ, Ley TJ, Caughey GH. Dipeptidyl peptidase I is essential for activation of mast cell chymases, but not tryptases, in mice. J Biol Chem (2001) 276:18551-6. doi:10.1074/jbc.M100223200

128. Wex T, Buhling F, Wex H, Gunther D, Malfertheiner P, Weber E, et al. Human cathepsin W, a cysteine protease predominantly expressed in NK cells, is mainly localized in the endoplasmic reticulum. J Immunol (2001) 167:2172-8. doi:10.4049/jimmunol.167.4.2172

129. Balaji KN, Schaschke N, Machleidt W, Catalfamo M, Henkart PA. Surface cathepsin B protects cytotoxic lymphocytes from self-destruction after degranulation. J Exp Med (2002) 196:493-503. doi:10.1084/jem.20011836 
130. Baran K, Ciccone A, Peters C, Yagita H, Bird PI, Villadangos JA, et al. Cytotoxic T lymphocytes from cathepsin B-deficient mice survive normally in vitro and in vivo after encountering and killing target cells. J Biol Chem (2006) 281:30485-91. doi:10.1074/jbc.M602007200

131. Punturieri A, Filippov S, Allen E, Caras I, Murray R, Reddy V, et al. Regulation of elastinolytic cysteine proteinase activity in normal and cathepsin K-deficient human macrophages. J Exp Med (2000) 192:789-99. doi:10.1084/ jem.192.6.789

132. Takayanagi $\mathrm{H}$. The unexpected link between osteoclasts and the immune system. Adv Exp Med Biol (2010) 658:61-8. doi:10.1007/978-1-4419-1050-9_7

133. Konjar S, Sutton VR, Hoves S, Repnik U, Yagita H, Reinheckel T, et al. Human and mouse perforin are processed in part through cleavage by the lysosomal cysteine proteinase cathepsin L. Immunology (2010) 131:257-67. doi:10.1111/j.1365-2567.2010.03299.x

134. Brown GR, McGuire MJ, Thiele DL. Dipeptidyl peptidase I is enriched in granules of in vitro- and in vivo-activated cytotoxic T lymphocytes. J Immunol (1993) 150:4733-42.

135. Sutton VR, Waterhouse NJ, Browne KA, Sedelies K, Ciccone A, Anthony D, et al. Residual active granzyme $\mathrm{B}$ in cathepsin C-null lymphocytes is sufficient for perforin-dependent target cell apoptosis. J Cell Biol (2007) 176:425-33. doi:10.1083/jcb.200609077

136. Soderstrom KO, Rinne R, Hopsu-Havu VK, Jarvinen M, Rinne A. Identification of acid cysteine proteinase inhibitor (cystatin A) in the human thymus. Anat $\operatorname{Rec}$ (1994) 240:115-9. doi:10.1002/ar.1092400111

137. Jarvinen M, Rinne A, Hopsu-Havu VK. Human cystatins in normal and diseased tissues - a review. Acta Histochem (1987) 82:5-18. doi:10.1016/S00651281(87)80043-0

138. Langerholc T, Zavasnik-Bergant V, Turk B, Turk V, Abrahamson M, Kos J. Inhibitory properties of cystatin $\mathrm{F}$ and its localization in U937 promonocyte cells. FEBS J (2005) 272:1535-45. doi:10.1111/j.1742-4658.2005.04594.x

139. Cappello F, Gatti E, Camossetto V, David A, Lelouard H, Pierre P. Cystatin F is secreted, but artificial modification of its C-terminus can induce its endocytic targeting. Exp Cell Res (2004) 297:607-18. doi:10.1016/j.yexcr.2004.03.048
140. Maher K, Konjar S, Watts C, Turk B, Kopitar-Jerala N. Cystatin F regulates proteinase activity in IL-2-activated natural killer cells. Protein Pept Lett (2014) 21:957-65. doi:10.2174/0929866521666140403124146

141. Hamilton G, Colbert JD, Schuettelkopf AW, Watts C. Cystatin F is a cathepsin C-directed protease inhibitor regulated by proteolysis. EMBO J (2008) 27:499-508. doi:10.1038/sj.emboj.7601979

142. Halfon S, Ford J, Foster J, Dowling L, Lucian L, Sterling M, et al. Leukocystatin, a new class II cystatin expressed selectively by hematopoietic cells. J Biol Chem (1998) 273:16400-8. doi:10.1074/jbc.273.26.16400

143. Ni J, Fernandez MA, Danielsson L, Chillakuru RA, Zhang J, Grubb A, et al. Cystatin $\mathrm{F}$ is a glycosylated human low molecular weight cysteine proteinase inhibitor. J Biol Chem (1998) 273:24797-804. doi:10.1074/jbc.273.38.24797

144. Magister S, Obermajer N, Mirkovic B, Svajger U, Renko M, Softic A, et al. Regulation of cathepsins $\mathrm{S}$ and $\mathrm{L}$ by cystatin F during maturation of dendritic cells. Eur J Cell Biol (2012) 91:391-401. doi:10.1016/j.ejcb.2012.01.001

Conflict of Interest Statement: The authors declare that the research was conducted in the absence of any commercial or financial relationships that could be construed as a potential conflict of interest.

Received: 01 October 2014; accepted: 18 November 2014; published online: 02 December 2014.

Citation: Perišić Nanut M, Sabotič J, Jewett A and Kos J (2014) Cysteine cathepsins as regulators of the cytotoxicity of $\mathrm{NK}$ and $\mathrm{T}$ cells. Front. Immunol. 5:616. doi: 10.3389/fimmu.2014.00616

This article was submitted to Tumor Immunity, a section of the journal Frontiers in Immunology.

Copyright (C) 2014 Perišić Nanut, Sabotič, Jewett and Kos. This is an open-access article distributed under the terms of the Creative Commons Attribution License (CC BY). The use, distribution or reproduction in other forums is permitted, provided the original author(s) or licensor are credited and that the original publication in this journal is cited, in accordance with accepted academic practice. No use, distribution or reproduction is permitted which does not comply with these terms. 